\title{
Seed metrics and influence of temperatures and pre-germination treatments on germination of Libidibia ferrea seeds
}

\author{
Arlete da Silva BANDEIRA ${ }^{1}$, Débora Leonardo dos SANTOS ${ }^{1}$, Maria Caroline Aguiar AMARAL ${ }^{2}$, \\ Manoel Nelson de CASTRO FILHO ${ }^{3}$, Caroline Boaventura Nascimento PENHA ${ }^{4 *}$, \\ Romana Mascarenhas Andrade GUGÉ1 \\ ${ }^{1}$ Universidade Estadual do Sudoeste da Bahia, Vitória da Conquista, BA, Brasil. \\ 2 Universidade Federal do Sul da Bahia, Itabuna, BA, Brasil. \\ 3 Universidade Federal de Viçosa, Viçosa, MG, Brasil. \\ ${ }^{4}$ Universidade Estadual de Santa Cruz, Ilhéus, BA, Brasil. \\ *E-mail: boaventuracaroline01@gmail.com \\ (Orcid: 0000-0001-9612-593X; 0000-0002-1655-5794; 0000-0002-1190-1352; 0000-0001-6783-9861; \\ 0000-0002-2116-2899; 0000-0001-5930-1092)
}

\begin{abstract}
Recebido em 27/01/2021; Aceito em 04/08/2021; Publicado em 23/08/2021.
ABSTRACT: The objective of this study was to evaluate seed metrics, optimum temperature for germination and efficiency of five pre-germination treatments for overcoming dormancy of $L$. ferrea seeds. Seeds were subjected to constant temperatures of $15,20,25,30$ and $35^{\circ} \mathrm{C}$ and to the following pre-germination treatments: nicking with pincers; immersion in water for 24 hours at room temperature; scarification with sandpaper; immersion in caustic soda for 60 minutes; and control (untreated seeds). Germination rate was assessed by germination percentage and germination speed index. The biometric characteristics of the evaluated seeds were: longitudinal length, width and thickness, using a digital caliper with a precision of $0.05 \mathrm{~mm}$. A completely randomized design was used with four replicates and means were compared by Tukey test at $5 \%$ probability. The best germination performance was obtained in the $15-30^{\circ} \mathrm{C}$ temperature range and by using chemical scarification with immersion in caustic soda, and mechanical scarification by nicking with pincers and by rubbing on sandpaper.
\end{abstract}

Keywords: dormancy; scarification; seed dimensions.

\section{Caracterização biométrica de sementes e influência de temperaturas e tratamentos pré-germinativos em pau-ferro}

\begin{abstract}
RESUMO: O objetivo do presente trabalho foi avaliar a biometria de sementes, a temperatura ótima e a eficiência de cinco tratamentos pré-germinativos para a superação de dormência das sementes de $L$. ferrea, sugeridos na literatura. As sementes foram submetidas a temperaturas constantes de $15,20,25,30$ e $35^{\circ} \mathrm{C}$ e aos tratamentos pré-germinativos: corte com alicate no lado oposto ao hilo, imersão em água por 24 horas em temperatura ambiente, escarificação com lixa d'água $n^{\circ} 4$, imersão em soda cáustica por 60 minutos e a testemunha (sem tratamento). A germinabilidade foi avaliada pela porcentagem de germinação e o índice de velocidade de germinação. As características biométricas das sementes avaliadas foram: comprimento longitudinal, largura e espessura, utilizando-se paquímetro digital com precisão de $0,05 \mathrm{~mm}$. O delineamento experimental foi inteiramente casualizado, e as médias foram comparadas pelo teste Tukey a 5\% de probabilidade. O melhor desempenho germinativo das sementes foi obtido nas temperaturas entre 15 e $30^{\circ} \mathrm{C}$ e nos tratamentos pré-germinativos de escarificação química com imersão em soda cáustica e escarificação mecânica por meio do desponte com alicate e o atrito em lixa.

Palavras-chave: dormência, escarificação, dimensão da semente.
\end{abstract}

\section{INTRODUÇÃO}

Libidibia ferrea Mart. ex Tul., commonly known in Brazil as pau-ferro or jucá, belongs to the family Caesalpiniaceae and is a typical tree species found in the Caatinga. This tree has high ornamental and medicinal potential (Silva et al., 2015), and its high-density wood is used in the lumber industry. Libidibia ferrea can be found from Piauí to Rio de Janeiro states due to its high seed dispersal.

Seed metrics is regarded as an important tool for detecting genetic variability within populations of a given species, thereby relating this variability to environmental factors, which provides important information for defining ecological characteristics such as seed dispersion, dispersion agents, and seedling setting (FERNANDES et al., 2012).
Temperature affects both germination percentage and speed at which germination occurs (Ranzani et al., 2016) owing to its direct impact on water uptake by seeds and on biochemical reactions regulating metabolic processes during germination. According to Carvalho; Nakagawa (2012), there is an optimum temperature range for germination in which the efficiency of the process is maximized, i.e., maximum germination in the least amount of time.

There is an increasing demand for native tree species due to environmental awareness programs (Nascimento et al., 2012); therefore, it is important to know the ideal condition for seed germination, especially because of different responses each tree species can have as a function of 
dormancy, viability and environmental conditions (CARVALHO; NAKAGAWA, 2012).

In numerous forest tree species, seeds are dormant due to an impermeable seed coat, as observed by Ataíde et al. (2013).

Seed dormancy represents an effective survival mechanism by preventing germination under unfavorable environmental conditions and by allowing time to germinate. Furthermore, it is a hereditary characteristic related to the palisade layer consisting of thick-walled wax-covered cells.

Seed dormancy of some species may be broken by rupturing the seed coat, process called scarification. In nature scarification is done by microorganisms, the digestive tract of animals, soil acidity and fire. As for artificial scarification, several methods are used, but one must not cross the scarification limit of the seed coat to prevent damaging the embryo.

Scarification can be chemical, such as using sulfuric acid (Freire et al., 2016) and caustic soda (Cipriani et al., 2019); mechanical, such as abrasion (Avelino et al., 2012); and physical, such as dipping seeds into boiling water (ATAÍDE et al., 2013). Among these, and according to the studies, mechanical scarification has been shown to be the most efficient to overcome seed dormancy (MISSIO et al., 2016).

The objective of this study was to evaluate the seed biometry, the influence of pre-germination treatments on seed dormancy seeking the best method for facilitating seed germination of $L$. ferrea, and to verify the temperature at which germination is optimum.

\section{MATERIAL E MÉTODOS}

\subsection{Seed collection and experimental area}

Ripe fruits of $L$. ferrea were manually collected in April 2016, in different trees.

The seeds were manually removed from pods with the aid of a hammer. After processing, seeds were selected and placed in glass containers (amber), sealed up, and stored in a refrigerator for 120 days.

\subsection{Seed characterization}

The seeds metrics was measured, with 100 seeds with 100 seeds in each treatment, were longitudinal length, measured from base to tip; width and thickness, both of which measured in the middle of the seed, using a $0.05 \mathrm{~mm}$ accuracy digital caliper.

Eight replicates consisting of 100 seeds each were used to determine the number of seeds in a kilogram. Seeds were randomly picked and then weighed on an analytical scale. Seed moisture content was measured by the oven drying method, at $105 \pm 3{ }^{\circ} \mathrm{C}$, during 24 hours, as standardized by the Rules for Seed Analysis (Brasil, 2009). We used four replicates and each replicate consisted of 50 seeds. Data are expressed as percentage based on fresh weight of the sample.

The experiment was carried out in a completely randomized design (CRD) $5 \times 5$ factorial experiment (five temperatures $\mathrm{x}$ five pre-germination treatments), with four replicates and each replicate consisted of 20 seeds.

\subsection{Experimental conditions and treatments}

Temperatures used were: $15,20,25,30$, and $35^{\circ} \mathrm{C}$, in a 12-hour photoperiod using fluorescent bulbs (Phillips 15W) in B.O.D. incubators (model 347 FANEN).

To overcome the coat-imposed seed dormancy, four pregermination methods were used: nicking with pincers on the opposite side to the hilum; immersion in water for 24 hours at room temperature; scarification with wet/dry sandpaper; and immersion in caustic soda for 60 minutes. Before setting up germination tests, seeds were immersed in a $5 \%$ sodium hypochlorite for 5 minutes and then rinsed in distilled water.

\subsection{Seeds immersed in water at room temperature}

Seeds were immersed in $150 \mathrm{~mL}$ of distilled water for 24 hours at room temperature.

\subsection{Chemical scarification}

A basic solution was prepared using water and caustic soda at $20 \%$ ( $65 \mathrm{~g}$ of caustic soda to $325 \mathrm{~mL}$ of water) following recommendations of Garcia \& Azevedo (1999). First, seeds were placed in a beaker; then, $65 \mathrm{~g}$ of caustic soda was added to the beaker containing the seeds; and, finally, $325 \mathrm{~mL}$ of distilled water was added to it, stirring the solution with a glass rod and letting it rest for 60 minutes. After removing seeds from the solution, caustic soda residues were rinsed off them.

\subsection{Mechanical scarification by nicking}

With the aid of pincers, seeds were nicked on the opposite side to the hilum to promote the rupture of the coat without damaging the embryo.

\subsection{Mechanical scarification using sandpaper}

Seeds were rubbed against a 40-grit wet/dry sandpaper on the opposite side to the micropyle to rupture the coat without damaging the embryo.

Seeds were sown in transparent gearbox-type boxes measuring $10 \times 10 \times 4 \mathrm{~cm}$ (length, width, and depth, respectively) containing vermiculite previously sterilized in oven for 24 hours at $200^{\circ} \mathrm{C}$ and wetted with distilled water. Moisture content in the substrate was maintained by watering it every two days in accordance with the field capacity of it.

\subsection{Germination characteristics}

Germination percentage ( $\%$ GERM), germination speed index (GSI), mean germination time (MGT), the day on which the first germination event occurs (NIG), and the day on which the last germination occurs (NFG) were evaluated.

Germinated seeds were counted daily when the radicle is emerged and seedlings were $2 \mathrm{~cm}$ long or more. Tests were brought to an end on the $50^{\text {th }}$ day when there were no germination events for three consecutive days. Maguire (1962), developed the following formula for the GSI (Equation 1):

$$
\mathrm{GSI}=\frac{\mathrm{G}_{1}}{\mathrm{~N}_{1}}+\frac{\mathrm{G}_{2}}{\mathrm{~N}_{2}}+\cdots+\frac{\mathrm{G}_{\mathrm{n}}}{\mathrm{N}_{\mathrm{n}}}
$$

where: $G_{1}, G_{2}, G_{n}=$ number of normal seedlings at first, second and last counting; $\mathrm{N}_{1}, \mathrm{~N}_{2}$ and $\mathrm{N}_{3}=$ number of days to first, second and last counting.

Labouriau; Valadars (1976) cited the formula used to calculate the germination time as follows (Equation 2):

$$
G T=i=1 k N i \times T i i=1 k N i
$$

where $\mathrm{Ni}=$ number of seeds germinated at time $\mathrm{Ti}$ (not the cumulative number, rather the number of the i-th observation); $\mathrm{Ti}$ $=$ time between sowing and the $\mathrm{i}$-th observation; $\mathrm{k}=$ last time at which seeds germinated. 
Length, width and thickness were subjected to exploratory analysis (descriptive statistics) of estimates. Results were assigned to classes and plotted as frequency distribution graphs (BEZERRA et al., 2012). The remaining characteristics were tested by analysis of variance using the $F$ test $(\mathrm{p} \leq 0.05)$. To compare means of pre-germination treatments, Tukey test at $5 \%$ probability was used. Regression models were adjusted to temperatures using SISVAR software (version 5.4) provided that means were significantly different (FERREIRA, 2014).

\section{RESULTS}

Weight of 1,000 seeds was $183.1 \mathrm{~g}$, which allows us to infer that a kilogram can contain 5,461 seeds of $L$. ferra.
Moisture content was $7.22 \%$, confirming that the seeds are orthodox. Mean seed size as to length, width and thickness were 9.9, 6.9 and $4.0 \mathrm{~mm}$, respectively (Table 1).

Coefficients of variation are below $20 \%$, which means that data are reliable. As for maximum and minimum values of measured variables, we observed differences of 3, 4.4 and $1.7 \mathrm{~mm}$, with the least variation for thickness. Regarding the standard deviation, seed thickness varied the least. This lower variability may be a result of genetic conditions and local environmental variations.

Figure 1 shows the frequency distribution of $L$. ferrea seed metrics as to length, width and thickness.

Most seeds had lengths varying from 9.6 to $10.6 \mathrm{~mm}$ $(32 \%)$; width between 6.3 and $6.9 \mathrm{~mm}(50 \%)$; and width between 4.2 and $4.4 \mathrm{~mm}(35 \%)$.

Table 1. Mean length, width and thickness of $100 \mathrm{~L}$. ferrea seeds.

Tabela 1. Valores médios de comprimento, largura e espessura de 100 sementes de L. ferrea.

\begin{tabular}{lccccc}
\hline Variables & Mean & Standard deviation & CV $(\%)$ & Minimum & Maximum \\
\hline Length $(\mathrm{mm})$ & 9.9 & 0.6 & 5.7 & 8.1 & 11.1 \\
Width $(\mathrm{mm})$ & 6.9 & 0.7 & 9.7 & 4.2 & 8.6 \\
Thickness $(\mathrm{mm})$ & 4.0 & 0.3 & 8.2 & 3.3 & 5.0 \\
\hline
\end{tabular}

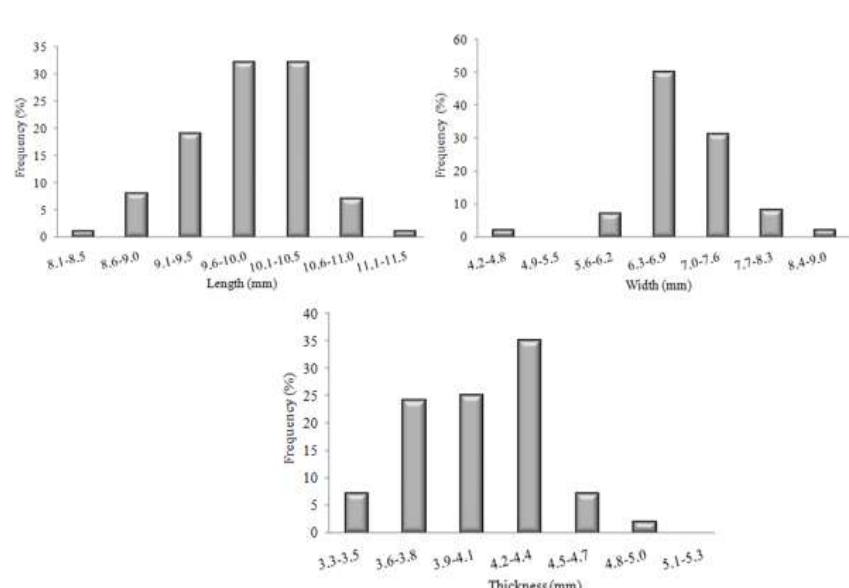

Figure 1. Length (A), width (B) and thickness (C) of L. ferrea, average values of 100 seeds.

Figura 1. Comprimento (A), largura (B) e espessura (E) de sementes de L. ferrea, valores médios de 100 sementes.

Curves yielded from slicing significant interactions between treatments for overcoming seed dormancy and temperatures are shown in Figures 2 and 3. Results indicated that interactions between these two factors had an influence on germination percentage, germination speed index, mean germination time, and number of days to start and finish germination of $L$. ferrea seeds tested at a significance level of $5 \%$. The data are best described by cubic and quadratic equations.

The highest estimated germination percentage $(110.0 \%)$ was recorded in seeds scarified with caustic soda at $24{ }^{\circ} \mathrm{C}$, more than $100 \%$ higher than that recorded in the control group (6.3\%); though, from $24{ }^{\circ} \mathrm{C}$ forth, germination decreased. As for mechanical scarification by nicking and rubbing against sandpaper, there is an increasing trend of germination up to $102.4 \%$ and $91.5 \%$ (estimated maximum point) at 24 and $22{ }^{\circ} \mathrm{C}$, respectively.

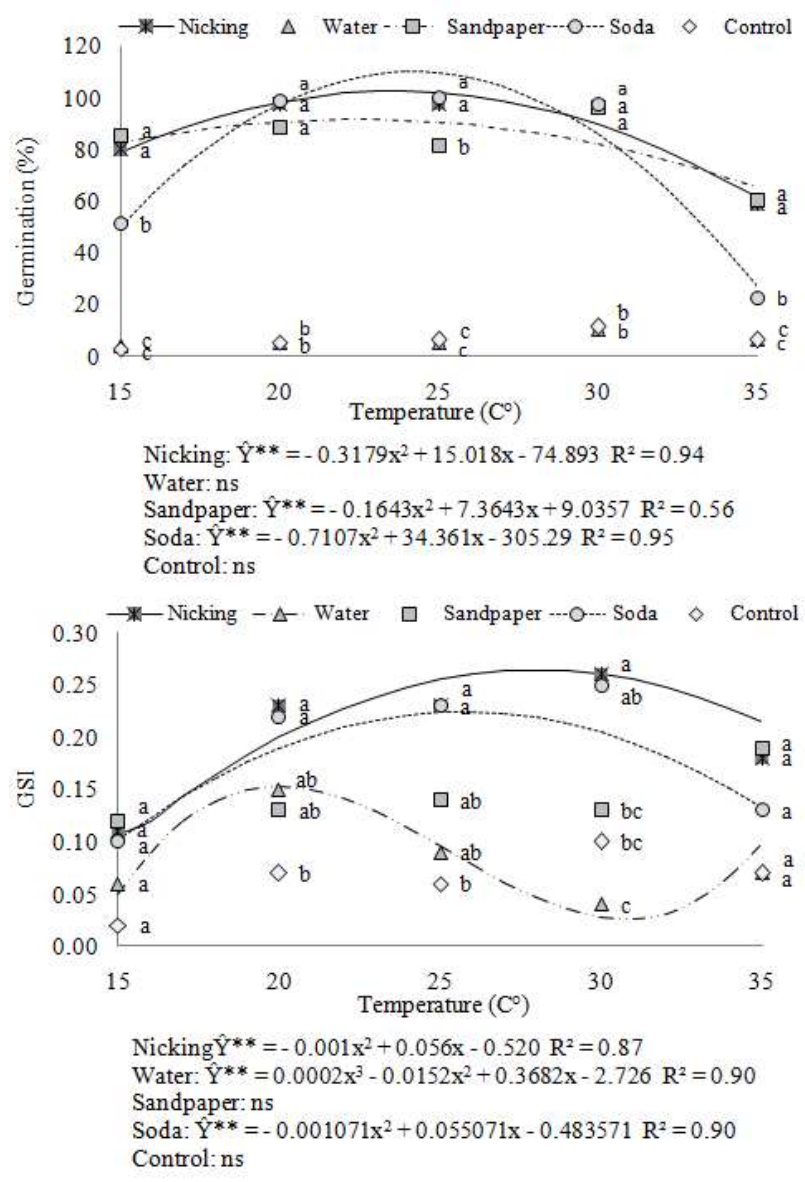

Figure 2. Final germination percentage (GERM) and germination speed index (GSI) of $L$. ferrea seeds subjected to different temperatures and pre-germination treatments. Different letters across treatments at each temperature differ from each other by Tukey test $(\mathrm{p}$ $\leq 0.05)$.

Figura 2. Porcentagem final de germinação (GERM) e índice de velocidade de germinação (IVG) de sementes de $L$. ferrea submetidas a diferentes temperaturas e tratamentos pré-germinativos. Letras diferentes entre os tratamentos para cada temperatura diferem entre si pelo teste de Tukey $(\mathrm{p} \leq 0,05)$. 
Seeds treated by nicking and rubbing against sandpaper had higher germination percentages in comparison with the remaining treatments at every temperature tested but $25^{\circ} \mathrm{C}$ at which nicking and caustic soda treatments were more efficient. At $20{ }^{\circ} \mathrm{C}$ and $30{ }^{\circ} \mathrm{C}$, germination percentage of seeds immersed in caustic soda was not significantly different from nicked seeds; however, untreated seeds and seeds immersed in water had the lowest germination percentages regardless of the temperature. These results demonstrate that L. ferrea seeds do have dormancy; therefore, efficient pregermination treatments are necessary for germination events to occur.

The interaction between the evaluated treatments indicated that the highest germination speed index (0.26) was obtained by using mechanical chiseling by topping, at a temperature of $25^{\circ} \mathrm{C}$, followed by immersion treatment, with an index of 0.22 , at temperature maximum of $23^{\circ} \mathrm{C}$. In the water immersion treatment, there was a higher germination speed index (0.15), at a temperature of $19^{\circ} \mathrm{C}$, after which there was a decrease up to $30^{\circ} \mathrm{C}$, with an index of 0.03 . It was also observed that without the use of efficient prescarification treatments, low rates of germination speed of pau-ferro seeds occur.

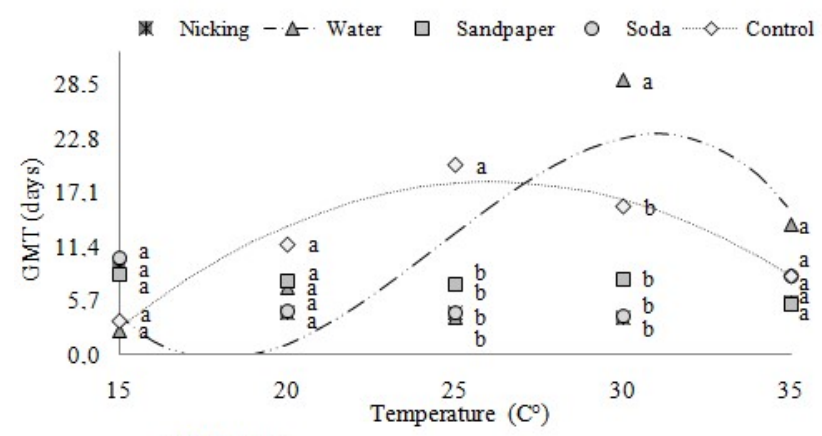

Nicking: ns

Water: $\hat{Y}^{* *}=-0.022 \mathrm{x}^{3}+1.592 \mathrm{x}^{2}-36.258 \mathrm{x}+262.87 \mathrm{R}^{2}=0.66$ Sandpaper: ns

Soda:ns

Control: $\hat{\mathrm{Y}}^{* *}=-0.124643 \mathrm{x}^{2}+6.505643 \mathrm{x}-66.6871 \mathrm{R}^{2}=0.95$

Figure 3. Mean germination time (GMT) of L. ferrea seeds subjected to different temperatures and pre-germination treatments. Different letters across treatments for each temperature differ from each other by Tukey's test $(\mathrm{p} \leq 0.05)$.

Figura 3. Tempo médio de germinação (TMG) de sementes de L. ferrea submetidas a diferentes temperaturas e tratamentos prégerminativos. Letras diferentes entre os tratamentos para cada temperatura diferem entre si pelo teste de Tukey ( $\mathrm{p} \leq 0,05)$.

The water immersion treatment for 24 hours promoted a shorter germination time ( 0 days $)$ at a temperature of $17^{\circ} \mathrm{C}$, after which there was an increase up to a temperature of 30 ${ }^{\circ} \mathrm{C}$, with an average time of 23 days. While, in the control, the average maximum germination time was 18 days, at $24^{\circ} \mathrm{C}$. The scarified seeds by topping, soda and sandpaper germinated faster, reaching the maximum average time of 5 , 6 and 7 days, respectively, after sowing (Figure 3).

Seeds scarified by caustic soda, nicking or sandpaper germinated faster, reaching the maximum mean time of 10 days after sowing. After initiating tests, we recorded germination events up to the $20^{\text {th }}$ and $29^{\text {th }}$ day in control and immersion in water, respectively.

As for the number of days to germination as a function of temperature, regressions were significant only for the treatments control and immersion in water. Germination events of these treatments were delayed compared to the remaining treatments (Figure 4). Maximum mean time to start germination of untreated seeds was 13 days at $27^{\circ} \mathrm{C}$ whereas for immersion in water at room temperature, the higher the temperature, the longer seeds take to germinate.
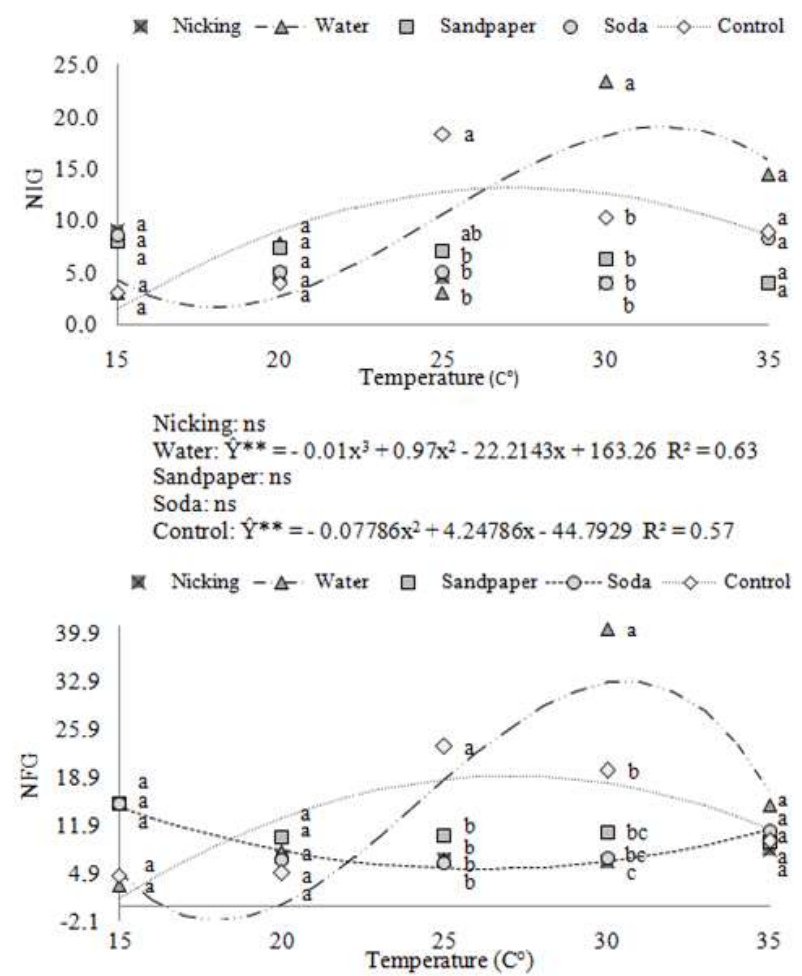

Figure 4. Number of days to germination (NIG) and number of days to finish germination (NFG) of L. ferrea seeds subjected to different temperatures and pre-germination treatments. Different letters across treatments at each temperature differ from each other by Tukey test ( $\mathrm{p}$ $\leq 0.05)$.

Figura 4. Número de dias para início da germinação (NIG) e número de dias para finalizar a germinação (NFG) de sementes de L. férrea submetidas a diferentes temperaturas e tratamentos prégerminativos. Letras diferentes entre os tratamentos para cada temperatura diferem entre si pelo teste de Tukey ( $\mathrm{p} \leq 0,05)$.

The number of days to finish germination as a function of temperatures yielded a significant regression for immersion in water, caustic soda and control (Figure 4). Caustic soda reduced the number of days to finish germination up to $26^{\circ} \mathrm{C}$, and from there on, number of days rose up again, while control treatment had an inverse behavior. NFG increases in the control group up to $27^{\circ} \mathrm{C}$, and from there on, it decreases. Immersing seeds in water at room temperature shortened number of days to finish germination between 15 and $20{ }^{\circ} \mathrm{C}$. From the latter temperature on, subsequent increments varied, then, past 30 ${ }^{\circ} \mathrm{C}$ germination decreased again.

\section{DISCUSSION}

Moisture content is consistent with that recorded by Lima et al. (2006) and Alves et al. (2009), which reported moisture contents of $7.46 \%$ and $6.9 \%$ in their studies with seeds of the same species evaluated in our study. This low seed moisture content lengthens viability of seeds (MATOS, 2015).

Seed metrics is fundamental for characterization of a seed lot by providing information about different sizes and storage 
content of seeds. According to Silva et al. (2012), these differences might be linked to strategies of using nutrients and available water resources, to local environmental variations, and to the own genotypic diversity of populations that might result in different phenotype characteristics for the species.

Pereira et al. (2011) demonstrated that Hymenaea stigonocarpa var. stigonocarpa has major variation in fruit size and seed weight. Silva et al. (2012) differentiated Hymenaea intermedia Ducke from Hymenaea martiana Hayne by comparing seed metrics and emphasized the importance of assessing seed metrics when differentiating species.

Untreated seeds and seeds immersed in water at different temperatures had low germination percentage, which indicates that in the absence of a scarification pretreatment, germination events are slow, uneven and, therefore, unsuitable for seedling production, due to the presence of a coat-imposed dormancy (COELHO et al., 2013). Conversely, the use of efficient pre-germination treatments, such as chemical scarification with caustic soda, and mechanical scarification by either nicking or rubbing against sandpaper, can result in high germination rates.

The optimum temperature range to germinate seeds is within what Brancalion et al. (2010) reported because seeds of most tropical and subtropical forest species have maximum potential for germination in the 25 to $30^{\circ} \mathrm{C}$ range. Germination events occur more rapidly and efficiently within an optimum temperature range, which, however, depends on the species and the species' regions of origin.

Temperature influences biochemical reactions of germination, which may affect both capacity and speed of seed germination. Seeds germinate most readily when they are in the characteristic temperature range of the species; however, the time taken to obtain the maximum germination percentage is dependent on the temperature. Increasing temperature makes water more fluid and with more kinetic energy, facilitating its movement from the outer to the inner side of the seed and, in consequence, water uptake is increased, so is the speed of metabolic reactions.

Based on findings of this study, we recommend the use of chemical scarification by immersion in caustic soda, mechanical scarification by nicking with pincers and by rubbing against sandpaper as the most efficient techniques to overcome seed dormancy within the optimum temperature range of 20 to $30{ }^{\circ} \mathrm{C}$. The optimum temperature for germination is a physiological adaptation of seeds to local environmental conditions where the species occurs or is grown; thus, this temperature may have a direct relationship with the biome in which the seeds were produced. Species with different ecological and geographical distributions produce seeds varying as to temperature requirements for germination (BRANCALION et al., 2010).

Mechanical scarification of the seed coat was efficient when breaking the dormancy of seeds of various species of the family Fabaceae such as, Cassia fistula L. (Bezerra et al., 2014; Guedes et al., 2013), Erythrina velutina Willd (Santos et al., 2013), and Centrosema plumier Benth (GAMA et al., 2011).

The decision between chemical or mechanical scarification should be based upon factors other than efficiency. Chemical scarification is advantageous due to its speed and decreased labor requirements. Mechanical scarification is more laborious and takes longer when done manually; though, mechanical methods do not use chemical products, thereby avoiding accidents with these products.
Oliveira et al. (2017) pointed out that manual techniques, such as mechanical scarification by nicking, either on the opposite side to the hilum or at the tip where the seed attached to the pod, is more desirable since both have equal efficiency to overcome dormancy of $L$. ferrea seeds.

Generally, depending on the site where seeds are collected, due to soil characteristics of each region and to autecology of the sites, seed coat hardness and treatments to break dormancy can also vary (NASCIMENTO, 2018).

The highest germination speed indexes were obtained at $23{ }^{\circ} \mathrm{C}$ and $25{ }^{\circ} \mathrm{C}$ with immersion in caustic soda and scarification by nicking, respectively, which is consistent with Brancalion et al. (2010) who affirm that Brazilian arboreal species have a maximum potential for germination next to the 25 to $30^{\circ} \mathrm{C}$ range. Oliveira et al. (2014) evaluated the seed germination of four native Caatinga tree species (Sideroxylon obtusifolium (Roem \& Schult.), Myracrodruon urundewva (All.), Amburana cearensis (All.) and Schinopsis brasiliensis (Engel.), verified that the seeds of different species from the same ecological and climatic conditions present different germinative behavior as to the ideal germination temperature, but the optimum temperature range was on average from 20 to $30{ }^{\circ} \mathrm{C}$. Regarding seeds immersed in water, the behavior was inversed as GSI decreased from $20^{\circ} \mathrm{C}$ on, and then, there is an increasing trend past $30^{\circ} \mathrm{C}$. In the water immersion treatments and in the control, there were low levels of germination speed indexes of pau-ferro seeds, not being efficient.

Chemical and mechanical scarification treatments started and ended germination in a smaller number of days, compared to water immersion and control treatments. Scarification ruptures the integument through which larger amounts of water enter the seed in a shorter period of time, leading to turgidity and in consequence, hydrolytic enzymes are activated and the germination process begins.

By comparing scarification methods (nicking by pincers, rubbing against sandpaper and immersion in caustic soda), Zucareli et al. (2010) highlighted nicking as the most economically feasible and safest method; nonetheless, nonetheless, the nicking a large number of seeds might be little feasible.

\section{CONCLUSIONS}

Metrics of $L$. ferrea seeds is more variable as to length and width, and less variable as to thickness. Chemical scarification with immersion in caustic soda and mechanical scarification through topping with pliers provided the highest percentages and germination speeds, between temperatures 23 and $25^{\circ} \mathrm{C}$, and the shortest time to germination.

\section{REFERENCES}

ALVES, E. U.; BRUNO, R. D. L. A.; OLIVEIRA, A. P.; ALVES, A. U.; ALVES, A. U. Escarificação ácida na superação da dormência de sementes de pau ferro (Caesalpinea ferrea Mart. ex Tu. var. leiostachya Benth.). Revista Caatinga, Mossoró, v. 22, n. 1, p. 37-47, 2009.

ATAÍDE, G. M.; BICALHO, E. M.; DIAS, D. C. F. S.; CASTRO, R. V. O.; ALVARENGA, E. M. Superação da dormência das sementes de Delonix regia (Bojer ex Hook.) Raf. Revista Árvore, Viçosa, v. 37, n. 6, p. 1145-1152, 2013. DOI: $10.1590 / \mathrm{S} 0100-67622013000600016$

AVELINO, J. I.; LIMA, J. S.; RIBEIRO, M. C. C.; CHAVES, A. P.; RODRIGUES, G. S. O. Métodos de quebra de

Nativa, Sinop, v. 9, n. 3, p. 337-343, mai./jun. 2021. 
dormência em sementes de jucá (Caesalpinia ferrea Mart. ex Tul. var. ferrea). Revista Verde de Agroecologia e Desenvolvimento Sustentável, Pombal, v. 7, n. 1, p. 102-106, 2012.

BEZERRA, F. T. C.; ANDRADE, L. A.; BEZERRA, M. A. F.; PEREIRA, W. E.; FABRICANTE, J. R.; OLIVEIRA, L. S. B.; FEITOSA, R. C. Biometria de frutos e sementes e tratamentos pré-germinativos em Cassia grandis L. f. (Fabaceae). Semina: Ciências Agrárias, Londrina, v. 33, n. 1, p. 2863-2876, 2012. DOI: DOI:10.5433/16790359.2012v33Sup11p2863.

BEZERRA, F. T. C.; ANDRADE, L. A.; BEZERRA, M. A. F.; SILVA, M. L. M.; NUNES, R. C. R.; COSTA, E. G. Biometria de frutos e sementes e tratamentos prégerminativos em Cassia fistula L. (Fabaceae: Caesalpinioideae). Semina: Ciências Agrárias, Londrina, v. 35, n. 4, p. 2273-2286, 2014. DOI: 10.5433/16790359.2014v35n4Suplp2273.

BRANCALION, P. H. S.; NOVEMBRE, A. D. D. L. C.; RODRIGUES, R. R. Temperatura ótima de germinação de sementes de espécies arbóreas brasileiras. Revista Brasileira de Sementes, Londrina, v. 32, n. 4, p. 15-21, 2010. DOI: $10.1590 /$ S0101-31222010000400002.

BRASIL_MINISTÉRIO DA AGRICULTURA E REFORMA AGRÁRIA. Regras para análise de sementes. Brasília: SNDA/DNDV/CLAV, 2009. 398p.

CARVALHO, N. M.; NAKAGAWA, J. Sementes: ciência, tecnologia e produção. 5 ed. Jaboticabal: FUNEP; 2012. 590p.

CIPRIANI, V. B.; GARLET, J.; LIMA, B. M. DE. Quebra de dormência em sementes de Chloroleucon acacioides e Senna macranthera. Revista de Ciências Agrárias, Lisboa, v. 42, n. 1, p. 49-54, 2019. DOI:10.34117/bjdv7n1-759.

COELHO, M. F. B.; CAVALCANTE NETO, M. H.; BARBOSA, M. K. R.; OLIVEIRA, M. C.; LIMA, A. K. B.; SOUZA, J. W. N. Superação da dormência em sementes de Caesalpinia ferrea Mart. ex Tul. var. ferrea de duas populações. Revista Verde de Agroecologia e Desenvolvimento Sustentável, Pombal, v. 8, n. 4, p. 179-182, 2013.

FERNANDES, M. R.; BARBOZA, M. P.; LEAL, T. S.; MORAES, C. P. de. Morfobiometria carpo seminal e germinação de Lafoensia pacari A. St. Hil. (Lythraceae) exposta a diferentes concentrações de GA3. Semina: Ciências Agrárias, Londrina, v. 33, n. 1, p. 2571-2584, 2012. DOI: 10.5433/1679-0359.2012v33Supl1p2571.

FERREIRA, D. F. Sisvar: a Guide for its Bootstrap procedures in multiple comparisons. Ciência e Agrotecnologia, Lavras, v. 38, n. 2, p. 109-112, 2014. DOI: 70542014000200001

FREIRE, J. M.; ATAÍDE, D. H. DOS S.; ROUWS, J. R. C. Superação de Dormência de Sementes de Albiz̧ia pedicellaris (DC.) L. Rico. Floresta e Ambiente, Seropédica, v. 23, n. 2, p. 251-257, 2016.

GAMA, J. S. N.; ALVES, E. U.; BRUNO, R. L. A.; PEREIRA JUNIOR, L. R.; BRAGA JUNIOR, J. B. M.; MONTE, D. M. O. Superação de dormência em sementes de Centrosema plumieri Benth. Revista Brasileira de Sementes, Londrina, v. 33, n. 4, p. 645-653, 2011. DOI: 10.1590/S0101-31222011000400006.

GARCIA, L. C.; AZEVEDO, C. P. Métodos para superação da dormência de sementes florestais tropicais. Manaus: Embrapa Amazônia Ocidental, 1999 4p. (Instruções Técnicas, 1)

LABOURIAU, L. G.; VALADARES, M. E. On the germination of seeds Calotropis procera (Ait.) Ait. f. Academia Brasileira de Ciências, Rio de Janeiro, v. 48, n. 2, p. 263-284,1976.

LIMA, J. D.; ALMEIDA, C. C.; DANTAS, V. A. V.; SILVA, B. M. D. S.; MORAES, W. D. S. Effect of temperature and substrate on seed germination of Caesalpinia ferrea Mart. ex Tul. (Leguminosae, Caesalpinoideae). Revista Árvore, Viçosa, v. 30, n. 4, p. 513-518, 2006. DOI: 10.1590/S0100-67622006000400003.

MAGUIRE, J. D. Speed of germination-aid selection and evaluation for seedling emergence and vigor. Crop Science, Madison, v. 2, n. 2, p. 176-177, 1962. DOI: 10.2135/cropsci1962.0011183X000200020033x.

MATOS, A. C. B.; LIMA E BORGES, E. E.; SILVA, L. J. Fisiologia da germinação de sementes de Dalbergia nigra (Vell.) Allemão ex Benth. sob diferentes temperaturas e tempos de exposição. Revista Árvore, Viçosa, v. 39, n. 1, p. 115-125, 2015. DOI: 10.1590/010067622015000100011.

MISSIO, E. L.; SALDANHA, C. W.; MALDANER, J.; MORAIS, R. M.; STEFFEN, G. Escarificação mecânica em cilindro rotativo é viável para a superação da dormência de sementes de pau-ferro. Enciclopédia Biosfera, Goiânia, v. 13, n. 24, p. 476-485, 2016. DOI: 10.18677/EnciBio_2016B_043

NASCIMENTO, D. F.; LELES, P. S. S.; OLIVEIRA NETO, S. N.; MOREIRA, R. T. S.; ALONSO, J. M. Crescimento inicial de seis espécies florestais em diferentes espaçamentos. Cerne, Lavras, v. 18, n. 1, p. 159-165p, 2012. DOI: 10.1590/S010477602012000100019.

NASCIMENTO, V. G.; AZEREDO, G. A.; SOUZA, V. C. Sementes de saboneteira (Sapindus saponaria l.) submetidas a tratamentos pré-germinativos. Nucleus, Ituverava, v. 15, n. 1, p. 217-224, 2018. DOI: 10.3738/1982.2278.2711.

OLIVEIRA, G. M.; MATIAS, J. R.; RIBEIRO, R. C.; BARBOSA, L. G.; SILVA, J. E. S. B.; DANTAS, B. F. Germinação de sementes de espécies arbóreas nativas da Caatinga em diferentes temperaturas. Scientia Plena, Aracajú, v. 10, n. 4, p. 1-6, 2014.

OLIVEIRA, K. J. B.; LIMA, J. S. S.; ANDRADE, L. I. F.; NOVO JÚNIOR, J.; BENEDITO, C. P.; CRISPIM, J. F. Métodos para superação da dormência tegumentar em sementes de Caesalpinia ferrea Mart. ex Tul. Revista Verde de Agroecologia e Desenvolvimento Sustentável, Pombal, v. 12, n. 4, p. 648-654, 2017. DOI: 10.18378/rvads.v12i4.4893.

PEREIRA, S. R.; GIRALDELLI, G. R.; LAURA, V. A.; SOUZA, A. L. T. Tamanho de frutos e de sementes e sua influência na germinação de jatobá-do-cerrado (Hymenaea stigonocarpa var. stigonocarpa Mart. ex Hayne, Leguminosae - Caesalpiniaceae). Revista Brasileira de Sementes, Londrina, v. 33, n. 1, p. 141-148, 2011.

RANZANI, R. E.; LUZ, P. B.; MAROSTEGA, T. N.; SOBRINHO, S. P. Efeitos de diferentes substratos e temperaturas na germinação de sementes de Foeniculum vulgare. Revista Brasileira de Plantas Medicinais, Botucatu, v. 18, n. 1, p. 363-366, 2016. DOI: 10.1590/1983-084X/15_179 
SANTOS, L. W.; COELHO, M. F. B.; MAIA, S. S. S.; SILVA, R. C. P.; CANDIDO, W. S.; SILVA, A. C. Armazenamento e métodos para a superação da dormência de sementes de mulungu. Semina: Ciências Agrárias, Londrina, v. 34, n. 1, p. 171-178, 2013. DOI: 10.5433/1679-0359.2013v34n1p171.

SILVA, G. R. C.; RODRIGUES, C. M.; MIRANDA, S. C. Dados biométricos de frutos e sementes de Hymenaea courbaril var. Stilbocarpa (Hayne) YT Lee \& Langenh e $H$. martiana Hayne. Biotemas, Florianopolis, v. 25, n. 3, p. 121-127, 2012. DOI: $10.5007 / 2175$ 7925.2012v25n3p121.

SILVA, F. D. B.; SALES, M. A. G.; SÁ, O. R. M.; SANTANA, G. M.; DEUS, M. S. M.; CASTRO E SOUSA, J. M.; PERON, A. P.; FERREIRA, P. M. P. Potencial citotóxico, genotóxico e citoprotetor de extratos aquosos de Caesalpinia pyramidalis Tul., Caesalpinia ferrea Mart. e Caesalpinia pulcherrima Sw. Revista brasileira de Biociências, Porto Alegre, v. 13, n. 2, p. 101-109, 2015.

ZUCARELI, V.; AMARO, A. C. E.; SILVÉRIO, E. V.; FERREIRA, G. Métodos de superação da dormência e temperatura na germinação de sementes de Dioclea violácea. Semina: Ciências Agrárias, Londrina, v. 31, n. 1, p. 1305-1312, 2010. 